\title{
CZĘSTOŚĆ WYSTĘPOWANIA ORAZ CZYNNIKI SKORELOWANE Z BÓLEM MIESIĄCZKOWYM U ZDROWYCH STUDENTEK
}

\section{THE PREVALENCE AND CORRELATES OF MENSTRUAL PAIN IN HEALTHY UNIVERSITY STUDENTS}

\author{
Zakład Anatomii Prawidłowej i Topograficznej Pomorskiego Uniwersytetu Medycznego w Szczecinie \\ al. Powstańców Wlkp. 72, 70-111 Szczecin \\ Kierownik: dr hab. n. med. Zbigniew Ziętek \\ Zakład Antropologii Instytutu Zoologii Uniwersytetu Jagiellońskiego \\ ul. Gronostajowa 9, 30-387 Kraków \\ Kierownik: dr hab. Henryk Głab
}

\section{Summary}

Introduction: Menstrual disorders generally affect the daily activities of females, and menstrual pain is a common gynaecological complaint in westernized societies.

The aim of the study was to determine the prevalence of, and the factors related to, menstrual pain in young, healthy women.

Material and methods: Data from 600 university students were obtained during the cross sectional survey. Students were asked to complete an anonymous questionnaire. Information on the women's socioeconomic status, age at menarche, and menstrual cycle characteristics: i.e. the length and regularity of cycles, the duration of menstrual flow, and the occurrence of menstrual pain, headache and back pain during the cycles were asked about. Each person's height, weight and waist circumference were measured, and the following indices: BMI, WHR, and WHtR were calculated.

Results: $29.8 \%$ of the surveyed students reported the occurrence of moderate pain during menstruation, and $21.7 \%$ reported the occurrence of severe menstrual pain. Significant differences were observed in the prevalence of menstrual pain with relation to age at menarche and the amount and distribution of adipose tissue. Menstrual pain was more prevalent among women who experienced menarche at a younger age. Among overweight and obese students, as well as among students with abdominal obesity, menstrual pain was more frequent than among those with correct weight and correct waist circumference. Moreover, psychological stress was associated with menstrual pain.
Conclusion: The results of this study show that a significant percentage of young women complain of menstrual pain. Menstrual pain is associated with early age at menarche, obesity and abdominal obesity.

K e y w o r d s: menstrual pain - menstruation disorders age at menarche - obesity - abdominal obesity - socioeconomic status.

\section{Streszczenie}

Wstęp: Zaburzenia cyklu miesiączkowego mogą znacząco wpływać na codzienną aktywność kobiet, a ból miesiączkowy jest powszechną dolegliwością, na jaką uskarżają się kobiety w zachodnich społeczeństwach.

Celem pracy było określenie częstości występowania dysmenorrhoea oraz czynników związanych z bólem miesiączkowym u młodych, zdrowych kobiet.

Materiat i metody: Dane zostały zebrane podczas badań przekrojowych przeprowadzonych w latach 2012-2014. Poproszono 600 studentek o wypełnienie anonimowego kwestionariusza, który zawierał informacje na temat ich statusu społeczno-ekonomicznego, wieku menarche oraz charakterystyki cyklu miesięcznego: długości i regularności cykli, długości krwawienia, występowania bólu miesiączkowego, bólu głowy oraz kręgosłupa w czasie cyklu. U każdej osoby dokonano także pomiaru wysokości, masy ciała, obwodu pasa oraz obliczono wskaźniki BMI, WHR, WHtR. 
Wyniki: Występowanie umiarkowanego bólu w trakcie menstruacji zadeklarowało $29,8 \%$ badanych studentek, natomiast $21,7 \%$ ankietowanych podało, że w trakcie miesiączki odczuwają ostry ból. Zanotowano znaczące różnice w częstości występowania bólu miesiączkowego w zależności od wieku menarche oraz ilości i rozmieszczenia tkanki tłuszczowej. Ból miesiączkowy był częstszy u kobiet, u których pierwsza miesiączka wystąpiła w młodszym wieku. Wśród otyłych studentek oraz wśród studentek z otyłością brzuszną ból miesiączkowy występował częściej niż u osób z prawidłową masą ciała oraz prawidłowym obwodem pasa. Dodatkowo ból miesiączkowy był skorelowany z narażeniem na stres psychologiczny.

Wnioski: Na podstawie wyników prezentowanych badań wykazano, że znaczący procent młodych kobiet doświadcza bólu miesiączkowego. Jego występowanie jest związane $\mathrm{z}$ wczesnym wiekiem menarche, otyłością oraz otyłością brzuszną.

H a s $\nmid$ a: ból miesiączkowy - zaburzenie cyklu menstruacyjnego - wiek menarche - otyłość - otyłość brzuszna - status społeczno-ekonomiczny.

\section{Wstęp}

Zaburzenia w przebiegu cyklu menstruacyjnego są częstym zjawiskiem wśród kobiet w każdym wieku. Mogą być one konsekwencją i pierwszym zewnętrznym objawem wielu chorób, głównie układu rozrodczego lub hormonalnego [1]. Badania monitoringowe pokazują jednak, że zdarzają się one również u zdrowych kobiet $[1,2,3,4]$. Uważa się, że ich występowaniu sprzyja niewłaściwy tryb życia, źle zbilansowana pod względem kalorii i doboru składników odżywczych dieta, mała aktywność fizyczna, narażenie na stres $[4,5,6]$. Wymienione czynniki są obecnie powszechnymi elementami stylu życia wielu kobiet w krajach wysoko uprzemysłowionych.

Ból miesiączkowy to jedna z najczęściej deklarowanych przez kobiety dolegliwości. Szczególnie często występuje u kobiet, które jeszcze nie rodziły. Częstość występowania bólu brzucha w trakcie miesiączki w wielu grupach szacuje się na $>50 \%[7,8]$. Wyniki badań przeprowadzonych w Polsce wykazały, że 56,3\% warszawskich kobiet w wieku 15-37 lat uskarża się na tę dolegliwość [9]. Według badań przeprowadzonych przez Skrzypulec $i$ wsp. w grupie kobiet wyczynowo uprawiających sport występowanie bólu miesiączkowego zadeklarowało $40 \%$, a w grupie kontrolnej $12 \%$ [10]. Wśród krakowskich studentek zadeklarowało go $54 \%$ osób, w tym $12 \%$ określiło ból jako silny [11]. Wyniki badań przeprowadzonych wśród studentek z innych państw pokazują równie wysoką częstość występowania bólu brzucha w trakcie miesiączki $[8,12,13]$.

Występowanie dolegliwości bólowych w trakcie miesiączki znacząco wpływa na jakość życia kobiety, obniża jej aktywność społeczną, utrudnia wykonywanie codziennych obowiązków w życiu osobistym i zawodowym, jest przyczyną nieobecności w pracy, na zajęciach w szkole lub na uczelni, a także mniejszej wydajności w pracy fizycznej i umysłowej [14]. Może się także wiązać z nadużywaniem leków przeciwbólowych. Biorąc pod uwagę liczbę kobiet odczuwających ból w trakcie miesiączki oraz konsekwencje dla codziennego życia, uzasadnione jest prowadzenie badań nad czynnikami sprzyjającymi występowaniu bólu.

Celem pracy było określenie czynników skorelowanych z występowaniem bólu miesiączkowego wśród studentek.

\section{Material i metody}

Dane będące podstawą analizy zebrano w trakcie badań antropologicznych i ankietowych przeprowadzonych wśród studentek w latach 2012-2014. Do dalszej analizy zakwalifikowano dane od 600 osób. Kryterium doboru było niestosowanie doustnej terapii hormonalnej. Z analizy wykluczono wszystkie studentki, które zadeklarowały, że pozostają pod stałą kontrolą lekarza i stale przyjmują leki. Wykluczono także kobiety, które urodziły dzieci. Badane osoby były w wieku 18-25 lat, a średni wiek w badanej grupie wynosił 20,03 $\pm 1,39$, natomiast mediana wieku wynosiła 20 lat. Wiek ginekologiczny wynosił średnio 7,24 $\pm 1,87$, zaś zakres zmienności mieścił się $\mathrm{w}$ przedziale 3-15 lat.

U każdej osoby dokonano pomiaru wysokości, masy ciała i obwodu pasa oraz obliczono wskaźniki BMI, WHR i WHtR wg wzorów:

$$
\begin{aligned}
& \mathrm{BMI}=\frac{\text { masa }}{(B-v)^{2}} \\
& \mathrm{WHR}=\frac{\text { obwód pasa }}{\text { obwód bioder }} \\
& \mathrm{WHtR}=\frac{\text { obwód pasa }}{B-v}
\end{aligned}
$$

Wiek pierwszej miesiączki ustalono metodą retrospektywną na podstawie daty podanej przez badane. Za pomocą ankiety zebrano dane dotyczące przebiegu cykli miesięcznych. Narzędziem badawczym był samodzielnie przygotowany kwestionariusz badawczy, w którym zawarto szczegółowe pytania dotyczące przebiegu cyklu menstruacyjnego (regularność i długość cykli, długość krwawienia, bolesność miesiączek, występowanie bólu głowy oraz kręgosłupa). W ankiecie zawarto także pytania dotyczące statusu społeczno-ekonomicznego. Dodatkowo, ankietowane w skali $1-5$ oceniały narażenie na stres w ciągu ostatniego roku.

\section{Analiza statystyczna}

Zgodność rozkładów empirycznych analizowanych zmiennych z rozkładem normalnym oceniono za pomoca testu Shapiro-Wilka. Istotność różnic pomiędzy grupami 
oceniano za pomoca jednoczynnikowej analizy wariancji. Dane procentowe porównano za pomocą testu $\chi^{2}$. W ocenie istotności efektów przyjęto poziom $\mathrm{p}<0,05$.

\section{Wyniki}

Spośród badanych studentek 291 (48,5\%) zadeklarowało, że nie odczuwa bólu w trakcie miesiączki, 179 (29,8\%) podało, że odczuwa ból o średnim nasileniu, natomiast 130 $(21,7 \%)$, że w trakcie miesiączki odczuwa silny ból.

W pierwszej kolejności sprawdzono, czy istnieje związek pomiędzy bolesnością miesiączek a innymi parametrami związanymi ze stanem zdrowia, takimi jak: regularność cykli, długość cykli, liczba dni krwawienia, odczuwanie bólu głowy i kręgosłupa. Wyniki zawarto w tabeli 1. Studentki o regularnych cyklach nieco częściej deklarują odczuwanie bólu w trakcie miesiączki, jednak różnica nie jest statystycznie istotna. Również nieistotne były różnice $\mathrm{w}$ długości cykli $(\mathrm{F}=0,35 ; \mathrm{p}=0,7046)$, które wynosiły kolejno dla grupy kobiet o miesiączkach: bezbolesnych $28,3 \pm 2,1$, średnio bolesnych $28,4 \pm 2,08$ i bardzo bolesnych $28,6 \pm 2,5$. Zanotowano natomiast niewielkie, ale statystycznie istotne różnice w liczbie dni krwawienia $(\mathrm{F}=3,88 ; \mathrm{p}=0,0213)$. Przeciętna liczba dni krwawienia wynosiła dla grupy kobiet o miesiączkach: bezbolesnych $5,0 \pm 1,2$, średnio bolesnych $5,1 \pm 1,2$ i bardzo bolesnych $5,4 \pm 1,1$.

Nie stwierdzono zależności pomiędzy występowaniem bólu w trakcie miesiączki a częstością występowania bólu głowy, chociaż studentki, które deklarują częste występowanie bólu głowy, najczęściej deklarują również ból w trakcie miesiączki. W przypadku bólu kręgosłupa, kobiety, które deklarowały, że nigdy go nie odczuwają, znacznie rzadziej od pozostałych deklarowały występowanie bólu miesiączkowego (tab. 1).
Kolejnym problemem była zależność pomiędzy występowaniem bólu miesiączkowego a wybranymi parametrami antropologicznymi i tempem dojrzewania. Zróżnicowanie budowy ciała pomiędzy wydzielonymi grupami przedstawiono w tabeli 2. Skupiono się na wskaźnikach antropologicznych skorelowanych z ryzykiem występowania różnych chorób, a więc BMI, który jest wyznacznikiem prawidłowej masy ciała i ilości tkanki tłuszczowej oraz WHR, WHtR i obwodzie pasa, które są wskaźnikami ilości tkanki tłuszczowej umieszczonej centralnie. Studentki, które deklarowały, że odczuwają ból w trakcie miesiączki, charakteryzują się wyższymi wartościami BMI, obwodu pasa, WHR i WHtR niż studentki, których miesiączki są bezbolesne (tab. 2). Stosując kryterium Światowej Organizacji Zdrowia (World Health Organization - WHO), badane podzielono na osoby z niedoborem masy ciała $(\mathrm{BMI}<18,5)$, osoby o prawidłowej w stosunku do wysokości masie ciała $(\mathrm{BMI}=18,5-25)$ i osoby $\mathrm{z}$ nadwagą i otyłością (BMI > 25). Studentki z nadwagą i otyłością najczęściej deklarowały ból miesiączkowy. Pomimo że studentki z niedoborem masy ciała najrzadziej deklarowały ból miesiączkowy, większość, która odczuwała ból miesiączkowy, klasyfikowała go jako silny (tab. 3). Ból miesiączkowy występował częściej u kobiet z otyłością brzuszną (obwód pasa $>80 \mathrm{~cm}$ ) niż w przypadku kobiet bez otyłości brzusznej (o obwodzie pasa poniżej $<80 \mathrm{~cm}$ ). Badane studentki podzielono również na 4 grupy wg wartości WHtR i zgodnie z kryteriami Ashewell Associates [15]. Jako sylwetkę „,chili” o zbyt małej ilości brzusznej tkanki tłuszczowej uznaje się osoby o wskaźniku niższym od 0,4; sylwetkę ,gruszka” o prawidłowej ilości tkanki tłuszczowej umieszczonej centralnie wyznacza wartość wskaźnika 0,4-0,5; WHtR w zakresie 0,5-0,6 wyznacza sylwetkę „kiwi” i wskazuje na nadmiar tkanki tłuszczowej umieszczonej centralnie, natomiast wartości $>0,6$ wskazują już na otyłość brzuszną. Ze względu na małą liczebność w ostatniej grupie połączono ją z grupą 3 .

T a b e 1 a 1. Częstość występowania bólu miesiączkowego w zależności od występowania zaburzeń cyklu menstruacyjnego oraz bólu głowy i kręgosłupa

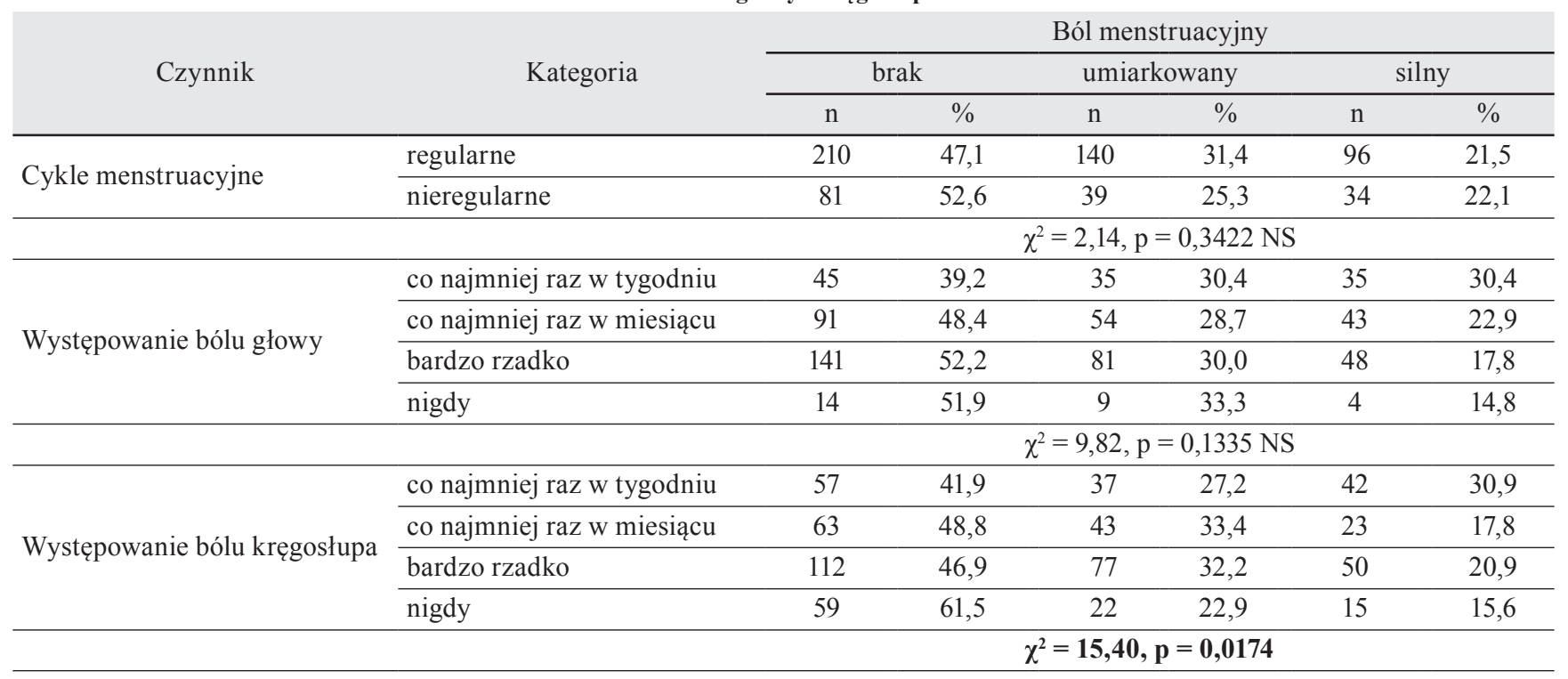


T a b e 1 a 2. Charakterystyka antropologiczna badanych studentek w zależności od odczuwania bólu miesiączkowego

\begin{tabular}{|c|c|c|c|c|c|}
\hline \multirow{2}{*}{\multicolumn{2}{|c|}{ Czynnik }} & \multicolumn{3}{|c|}{ Ból menstruacyjny } & \\
\hline & & brak & umiarkowany & silny & \\
\hline \multirow{3}{*}{ Wysokość ciała } & $\overline{\mathrm{x}}$ & 165,9 & 166,8 & 166,8 & \multirow{3}{*}{$\begin{array}{l}F=1,73 \\
p=0,1777\end{array}$} \\
\hline & $\mathrm{s}$ & 6,12 & 5,65 & 5,77 & \\
\hline & min.-maks. & $150-183$ & $154-181$ & $155-182$ & \\
\hline \multirow{3}{*}{ BMI } & $\overline{\mathrm{x}}$ & 20,04 & 23,79 & 21,00 & \multirow{3}{*}{$\begin{array}{l}F=\mathbf{1 0 6 , 8 4} \\
\mathbf{p}=\mathbf{0 , 0 0 0 0}\end{array}$} \\
\hline & $\mathrm{s}$ & 2,20 & 3,07 & 3,19 & \\
\hline & min.-maks. & $17,15-31,71$ & $17,93-36,80$ & $16,80-35,59$ & \\
\hline \multirow{3}{*}{ Obwód pasa } & $\overline{\mathrm{x}}$ & 68,0 & 76,9 & 70,9 & \multirow{3}{*}{$\begin{array}{l}\mathbf{F}=\mathbf{8 1 , 3 3} \\
\mathbf{p}=\mathbf{0 , 0 0 0 0}\end{array}$} \\
\hline & $\mathrm{s}$ & 5,83 & 8,90 & 8,22 & \\
\hline & min.--maks. & $58-98$ & $60-106$ & $59-106$ & \\
\hline \multirow{3}{*}{ WHR } & $\overline{\mathrm{x}}$ & 0,73 & 0,77 & 0,75 & \multirow{3}{*}{$\begin{array}{l}F=19,96 \\
p=0,0000\end{array}$} \\
\hline & $\mathrm{s}$ & 0,06 & 0,07 & 0,07 & \\
\hline & min.--maks. & $0,65-1,01$ & $0,65-0,99$ & $0,62-1,10$ & \\
\hline \multirow{3}{*}{ WHtR } & $\overline{\mathrm{x}}$ & 0,41 & 0,46 & 0,43 & \multirow{3}{*}{$\begin{array}{l}F=70,24 \\
p=\mathbf{0 , 0 0 0 0}\end{array}$} \\
\hline & $\mathrm{s}$ & 0,04 & 0,05 & 0,05 & \\
\hline & min.--maks. & $0,35-0,61$ & $0,37-0,67$ & $0,35-0,63$ & \\
\hline
\end{tabular}

T a b e 1 a 3. Częstość występowania bólu miesiączkowego w zależności od tempa dojrzewania, występowania otyłości i otyłości brzusznej

\begin{tabular}{|c|c|c|c|c|c|c|c|}
\hline \multirow{3}{*}{ Czynnik } & \multirow{3}{*}{ Kategoria } & \multicolumn{6}{|c|}{ Ból menstruacyjny } \\
\hline & & \multicolumn{2}{|c|}{ brak } & \multicolumn{2}{|c|}{ umiarkowany } & \multicolumn{2}{|c|}{ silny } \\
\hline & & $\mathrm{n}$ & $\%$ & $\mathrm{n}$ & $\%$ & $\mathrm{n}$ & $\%$ \\
\hline \multirow{4}{*}{ Wiek menarche } & wczesny & 31 & 36,9 & 36 & 42,9 & 17 & 20,2 \\
\hline & przeciętny & 224 & 49,2 & 130 & 28,6 & 101 & 22,2 \\
\hline & późny & 36 & 59,0 & 13 & 21,3 & 12 & 19,7 \\
\hline & & \multicolumn{6}{|c|}{$\chi^{2}=10,52, p=0,0325$} \\
\hline \multirow{4}{*}{ Względna masa ciała } & niedobór & 63 & 69,2 & 2 & 2,2 & 26 & 28,6 \\
\hline & norma & 210 & 49,3 & 129 & 21,2 & 95 & 21,5 \\
\hline & nadwaga i otyłość & 10 & 14,9 & 40 & 71,6 & 9 & 13,5 \\
\hline & & \multicolumn{6}{|c|}{$\chi^{2}=90,42 p=0,000$} \\
\hline \multirow{4}{*}{ Otyłość brzuszna } & nie & 284 & 54,1 & 124 & 23,6 & 117 & 22,7 \\
\hline & tak & 7 & 9,3 & 55 & 73,4 & 13 & 17,3 \\
\hline & & \multicolumn{6}{|c|}{$\chi^{2}=82,22, p=0,0000$} \\
\hline & chili & 110 & 71,9 & 7 & 4,6 & 36 & 23,5 \\
\hline \multirow[t]{2}{*}{ Typ sylwetki } & gruszka & 175 & 44,0 & 137 & 34,4 & 86 & 21,6 \\
\hline & kiwi i jabłko & 6 & 12,3 & 35 & 71,4 & 8 & 16,3 \\
\hline
\end{tabular}

Ból miesiączkowy najczęściej deklarowały kobiety o sylwetce kiwi i jabłko, a więc z nadmierną ilością brzusznej tkanki tłuszczowej. Kobiety z bardzo małą ilością tkanki tłuszczowej umieszczonej centralnie najrzadziej deklarują występowanie bólu w trakcie miesiączki, jednak podobnie jak w przypadku niedoboru masy ciała, przeważający odsetek z odczuwających ból w trakcie miesiączki określa go jako silny.

Wyniki jednoczynnikowej analizy wariancji wykazały statystycznie istotne różnice w przeciętnym wieku dojrzewania pomiędzy wydzielonymi grupami $(\mathrm{F}=4,44$; $\mathrm{p}=0,0122)$. Przeciętny wiek menarche wynosił dla grupy kobiet o miesiączkach: bezbolesnych $12,93 \pm 1,33$, średnio bolesnych $12,60 \pm 1,26$, bardzo bolesnych 12,76 $\pm 1,28$.
Na podstawie wartości centylowych wieku menarche badane podzielono na 3 grupy dojrzewające wcześnie, czyli przed 12. r.ż. $(<25$ centyla), przeciętnie, czyli w granicach $12-14$ lat (w granicach $25-75$ centyla) i późno, $>14$ lat $(>75$ centyla). Wśród dziewcząt wcześnie dojrzewających znacznie więcej deklaruje ból w trakcie miesiączki niż wśród dojrzewających przeciętnie i późno. Różnice są statystycznie istotne (tab. 3).

Ostatnim analizowanym zagadnieniem była zależność pomiędzy bolesnością miesiączek a czynnikami społeczno-ekonomicznymi. Są one pośrednimi wyznacznikami stylu życia. Na podstawie danych $\mathrm{z}$ piśmiennictwa stwierdzono, że osoby z rodzin o wysokim statusie społeczno-ekonomicznym prowadzą bardziej prozdrowotny styl życia 
T a b e 1 a 4. Częstość występowania bólu miesiączkowego w zależności od statusu społeczno-ekonomicznego

\begin{tabular}{|c|c|c|c|c|c|c|c|}
\hline \multirow{3}{*}{ Czynnik } & \multirow{3}{*}{ Kategoria } & \multicolumn{6}{|c|}{ Ból menstruacyjny } \\
\hline & & \multicolumn{2}{|c|}{ brak } & \multicolumn{2}{|c|}{ umiarkowany } & \multicolumn{2}{|c|}{ silny } \\
\hline & & $\mathrm{n}$ & $\%$ & $\mathrm{n}$ & $\%$ & $\mathrm{n}$ & $\%$ \\
\hline \multirow{4}{*}{ Miejsce zamieszkania } & wieś & 92 & 48,7 & 52 & 27,5 & 45 & 23,8 \\
\hline & miasteczko & 101 & 46,8 & 65 & 30,1 & 50 & 23,1 \\
\hline & miasto & 98 & 50,3 & 62 & 31,8 & 35 & 17,9 \\
\hline & & \multicolumn{6}{|c|}{$\chi^{2}=2,72, p=0,6055 \mathrm{NS}$} \\
\hline \multirow{4}{*}{ Wykształcenie matki } & zawodowe & 46 & 50,5 & 27 & 29,7 & 18 & 19,8 \\
\hline & średnie & 93 & 44,9 & 66 & 31,9 & 48 & 23,2 \\
\hline & wyższe & 152 & 50,3 & 86 & 28,5 & 64 & 21,2 \\
\hline & & \multicolumn{6}{|c|}{$\chi^{2}=1,71, p=0,7883 \mathrm{NS}$} \\
\hline \multirow{4}{*}{ Wykształcenie ojca } & zawodowe & 95 & 44,2 & 66 & 30,7 & 54 & 25,1 \\
\hline & średnie & 92 & 49,7 & 54 & 29,2 & 39 & 21,1 \\
\hline & wyższe & 104 & 52,0 & 59 & 29,5 & 37 & 18,5 \\
\hline & & \multicolumn{6}{|c|}{$\chi^{2}=3,61, p=0,4613 \mathrm{NS}$} \\
\hline \multirow{5}{*}{ Liczba rodzeństwa } & 0 & 43 & 43,0 & 28 & 28,0 & 29 & 29,0 \\
\hline & 1 & 134 & 48,6 & 84 & 30,4 & 58 & 21,0 \\
\hline & 2 & 77 & 50,0 & 43 & 27,9 & 34 & 22,1 \\
\hline & 3 i więcej & 37 & 53,6 & 23 & 33,3 & 9 & 13,1 \\
\hline & & \multicolumn{6}{|c|}{$\chi^{2}=6,59, p=0,3603 \mathrm{NS}$} \\
\hline \multirow{5}{*}{ Stres psychologiczny } & 1 i $2-$ niski & 44 & 56,4 & 26 & 33,3 & 8 & 10,3 \\
\hline & 3 & 102 & 52,3 & 56 & 28,7 & 37 & 19,0 \\
\hline & 4 & 103 & 48,6 & 58 & 27,4 & 51 & 24,0 \\
\hline & 5 -wysoki & 41 & 36,0 & 39 & 34,2 & 34 & 29,8 \\
\hline & & \multicolumn{6}{|c|}{$\chi^{2}=16,24, p=0,0125$} \\
\hline
\end{tabular}

w porównaniu do osób o niskim statusie. Jest to wynikiem zarówno różnic w warunkach finansowych, jak i wiedzy z zakresu prawidłowego żywienia oraz profilaktyki chorób. W grupach wydzielonych ze względu na kategorię analizowanych zmiennych społeczno-ekonomicznych odsetek kobiet deklarujących występowanie bólu miesiączkowego był zbliżony i żadna z różnic nie była statystycznie istotna (tab. 4). Istotne różnice stwierdzono natomiast pomiędzy grupami wydzielonymi ze względu na natężenie poziomu stresu w ciągu ostatniego roku. Wraz ze wzrostem narażenia na sytuacje stresowe maleje odsetek kobiet deklarujących, że ich miesiączki są bezbolesne natomiast rośnie odsetek kobiet deklarujących odczuwanie bólu w trakcie miesiączki (tab. 4).

\section{Dyskusja}

Wyniki prezentowanych badań potwierdzają, że problem bolesności miesiączek dotyczy dużej liczby kobiet. Występowanie bólu nie było związane z regularnością i długością cykli. Kobiety odczuwające ból w trakcie miesiączki miały nieco dłuższe okresy krwawienia i częściej też odczuwały inne dolegliwości bólowe (szczególnie ból kręgosłupa) niż kobiety o bezbolesnych miesiączkach. Wyniki innych prac na temat zależności pomiędzy długością i regularnością cykli a występowaniem bólu miesiączkowego są rozbieżne. Część badaczy wskazuje na brak zależności [16], inni wykazali, że długie i nieregularne cykle zwiększają ryzyko $d y s-$ menorrhoea [6]. Podobnie do wyników własnych, również inni autorzy stwierdzili zależność pomiędzy bólem miesiączkowym a długością krwawienia [6, 17, 18, 19, 20].

Wyniki badań własnych oraz innych autorów pokazują, że istnieje związek pomiędzy występowaniem bólu miesiączkowego a tempem dojrzewania. Wczesny wiek menarche wiąże się z częstszym występowaniem bólu miesięcznego [2, 5, 20, 21, 22]. Zgodnie z wynikami badań własnych oraz innych autorów, ból miesiączkowy występuje częściej u kobiet z nadwagą i otyłością oraz z otyłością brzuszną [2]. Warto zaznaczyć, że obie zmienne są ze sobą powiązane. Wczesny wiek menarche sprzyja występowaniu otyłości oraz centralnemu rozmieszczeniu tkanki tłuszczowej $[23,24,25]$.

Wiele prac wskazuje na związek pomiędzy bólem miesiączkowym a sposobem żywienia [5, 26], aktywnością fizyczną [27], paleniem papierosów [17, 18], narażeniem na stres [28, 29]. Styl i warunki życia sa z kolei zależne od statusu społeczno-ekonomicznego. Niektóre wyniki badań wskazują na związek pomiędzy statusem społeczno-ekonomicznym a występowaniem bólu miesiączkowego [30], inne, analogicznie do wyników własnych, nie wykazują takiej zależności [26]. Brak różnic w częstości 
występowania bólu miesiączkowego pomiędzy grupami społeczno-ekonomicznych może wynikać z faktu, że badania były prowadzone wśród studentów, którzy mimo iż pochodzą z rożnych rodzin, stanowią obecnie grupę o w miarę jednolitym stylu życia.

Należy także wspomnieć o ograniczeniach prezentowanych badań. Pomimo że w pracy własnej starano się uwzględnić tylko zdrowe osoby, nie można wykluczyć, że u części z nich ból miesiączkowy jest wynikiem niediagnozowanych i nieleczonych poważniejszych schorzeń, np. endometriozy.

Podsumowując, wyniki własne potwierdzają wnioski innych autorów, które wskazują na związek pomiędzy wiekiem menarche i nadmierną ilością tkanki tłuszczowej a występowaniem bólu miesiączkowego. Biorąc pod uwagę fakt, że wiek menarche i otyłość są czynnikami ryzyka wielu chorób, a jak już wspomniano we wstępie pracy ból miesiączkowy może też być symptomem schorzeń układu rozrodczego, wyjaśnienie mechanizmu powyższej zależności może być pomocne w poznaniu etiologii, a następnie w profilaktyce wielu chorób. Określenie czynników ryzyka bólu miesiączkowego może się także znacząco przychylić do poprawy jakości życia wielu kobiet.

\section{Wnioski}

1. Ból miesiączkowy wśród młodych kobiet występuje często $-51,5 \%$ badanych studentek deklaruje odczuwanie bólu w takcie miesiączki, w tym 21,1\% określa ból jako silny.

2. Występowaniu bólu miesiączkowego sprzyja wczesny wiek menarche, nadwaga i otyłość oraz otyłość brzuszna.

3. Studentki, które oceniały swoją sytuację w ostatnim roku jako bardzo stresującą, częściej od pozostałych deklarowały występowanie bólu miesiączkowego.

\section{Piśmiennictwo}

1. Harlow S.D., Ephross S.A.: Epidemiology of menstruation and its relevance to women's health. Epidemiol Rev. 1995, 17, 265-286.

2. Chang P.J., Chen P.C., Hsieh C.J., Chiu L.T.: Risk factors on the menstrual cycle of healthy Taiwanese college nursing students. Aus N Z J Obstet Gynaecol. 2009, 49, 689-694.

3. Andersch B., Milsom I.: An epidemiologic study of young women with dysmenorrhea. Am J Obstet Gynecol. 1982, 144, 655-660.

4. Rowland A.S., Baird D.D., Long S., Wegienka G., Harlow S.D., Alabania $M$. et al.: Influence of medical conditions and lifestyle factors on the menstrual cycle. Epidemiology. 2002, 13, 668-674.

5. Balbi C., Musone R., Menditto A., Prisco L.D., Cassese E., D'Ajello M.: Influence of menstrual factors and dietary habits on menstrual pain in adolescence age. Eur J Obstet Gynecol Reprod Biol. 2000, 91, $143-148$.

6. Di Cintio E., Parazzini F., Tozzi L., Luchini L., Mezzopane R., Marchini M. et al.: Dietary habits, reproductive and menstrual factors and risk of dysmenorrhoea. Eur J Epidemiol. 1997, 13, 925-930.

7. Adams H.P.J., Deitch H.R.: Menstrual disorders in the college age female. Pediatr Clin North Am. 2005, 52, 179-197.
8. Polat A., Celik H., Gurates B., Kaya D., Nalbant M., Kavak E. et al.: Prevalence of primary dysmenorrhea in young adult female university students. Arch Gynecol Obstet. 2009, 279, 527-532.

9. Skierska E., Leszczynska-Bystrzanowska J., Gajewski A.K.: Risk analysis of menstrual disorders in young women from urban population. Przegl Epidemiol. 1996, 50, 467-474.

10. Skrzypulec V., Lindert O., Morawiec M., Nowosielski K., Drosdzol A., Klimanek M.: Zaburzenia miesiączkowania u sportsmenek. Ginek Prakt. 2005, 5, 28-51.

11. Wronka I., Teul I., Marchewka J.: The influence of age at menarche on the prevalence of disorders of menstrual cycle among healthy university students. Ann Acad Med Stetin. 2013, 59 (2), 94-99.

12. Anastasakis E., Kingman C.E., Lee C.A., Economides D.L. Kadir R.A.: Menstrual problems in university students: an electronic mail survey. In Vivo. 2008, 22, 617-620.

13. Ozerdogan N., Sayiner D., Ayranci U., Unsal A., Giray S.: Prevalence and predictors of dysmenorrhea among students at a university in Turkey. Int J Gynaecol Obstet. 2009, 107, 39-43.

14. Pitangui A.C.R., Gomes M.R., Lima A.S., Schwingel P.A., Albuquerque A.P.S., Araújo R.C.: Menstruation disturbances: prevalence, characteristics, and effects on the activities of daily living among adolescent girls from Brazil. J Pediatr Adolesc Gynecol. 2013, 26, 148-152.

15. Ashwell Associates. www.ashwell.uk.com (26.11.2014).

16. Cakir M., Mungan I., Karakas T., Girisken L., Okten A.: Menstrual pattern and common menstrual disorders among university students in Turkey. Pediatr Int. 2007, 49, 938-942.

17. Shye D., Jaffe B.: Prevalence and correlates of perimenstrual symptoms a study of Israeli teenage girls. J Adolesc Health. 1991, 12, 217-224.

18. Sundell G., Milsom I., Andersch B.: Factors influencing the prevalence and severity of dysmenorrhoea in young women. Br J Obstet Gynaecol. 1999, 97, 588-594.

19. Yamamoto K., Okazaki A., Sakamoto Y., Funatsu M.: The relationship between premenstrual symptoms, menstrual pain, irregular menstrual cycles, and psychosocial stress among Japanese college students. J Physiol Anthropol. 2009, 28, 129-136.

20. Harlow S.D., Park M.: A longitudinal study of risk factors for the occurrence, duration and severity of menstrual cramps in a cohort of college women. Br J Obstet Gynaecol. 1996, 103, 1134-1142.

21. Montero P., Bernis C., Loukid M., Hilali K., Baali A.: Characteristics of menstrual cycles in Moroccan girls: Prevalence of dysfunctions and associated behaviours. Ann Hum Biol. 1999, 26, 243-249.

22. Ng T.P., Tan N.C., Wansaicheong G.K.: A prevalence study of dysmenorrhoea in female residents aged 15-54 years in Clementi Town, Singapore. Ann Acad Med Singapore. 1992, 21, 323-327.

23. Wronka I., Pawlińska-Chmara R.: Wpływ tempa dojrzewania na kształtowanie się dorosłych proporcji wagowo-wzrostowych u dziewcząt. Wiad Lek. 2005, 5, 513-519.

24. Harris M.A., Prior J.C., Koehoorn M.: Age at menarche in the Canadian population: Secular trends and relationship to adulthood BMI. J Adolesc Health. 2008, 43, 548-554.

25. Hossain G., Islam S., Aik S., Zaman T.K., Lestrel P.E.: Age at menarche of university students in Bangladesh: secular trends and association with adult anthropometric measures and socio-demographic factors. J Biosoc Sci. 2010, 42, 677-687.

26. Deutch B.: Menstrual pain in Danish women correlated with low n-3 polyunsaturated fatty-acid intake. Eur J Clin Nutr. 1995, 49, 508-516.

27. Hightower M.: Effects of exercise participation on menstrual pain and symptoms. Women Health. 1997, 26, 15-27.

28. Hjollund N.H., Jensen T.K., Bonde J.P.: Stress and fertility. A follow-up study among couples planning the first pregnancy. Ugeskr Laeger. 2000, 162, 5081-5086.

29. Hatch M.C., Figa-Talamanca I., Salerno S.: Work stress and menstrual patterns among American and Italian nurses. Scand J Work Environ Health. 1999, 25, 144-150.

30. Klein J.R., Litt I.F.: Epidemiology of adolescent dysmenorrhea. Pediatrics. 1981, 68, 661-664. 